\title{
The histone methyltransferase EZH2 as a druggable target in SHH medulloblastoma cancer stem cells
}

\author{
Evelina Miele ${ }^{1,10, *}$, Sergio Valente ${ }^{2, *}, V_{i n c e n z o}$ Alfano $^{3}$, Marianna Silvano $^{3}$, Paolo \\ Mellini ${ }^{2}$, Diana Borovika ${ }^{4}$, Biagina Marrocco ${ }^{2}$, Agnese Po ${ }^{5}$, Zein Mersini Besharat ${ }^{5}$,

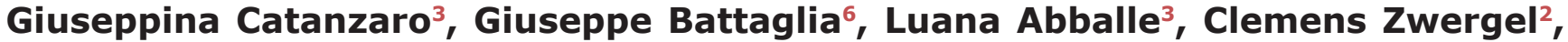 \\ Giulia Stazi ${ }^{2}$, Ciro Milite ${ }^{7}$, Sabrina Castellano ${ }^{7,8}$, Marco Tafani $^{3}$, Peteris Trapencieris ${ }^{4}$, \\ Antonello $\mathrm{Mai}^{2,9}$ and Elisabetta Ferretti ${ }^{3,6}$ \\ ${ }^{1}$ Center for Life NanoScience@Sapienza, Istituto Italiano di Tecnologia, Rome 00161, Italy \\ ${ }^{2}$ Department of Chemistry and Technologies of Drugs, Sapienza University of Rome, Rome 00185, Italy \\ ${ }^{3}$ Department of Experimental Medicine, Sapienza University of Rome, Rome 00161, Italy \\ ${ }^{4}$ Latvian Institute of Organic Synthesis, Riga LV-1006, Latvia \\ ${ }^{5}$ Department of Molecular Medicine, Sapienza University of Rome, Rome 00161, Italy \\ ${ }^{6}$ Neuromed Institute, Località Camerelle, Pozzilli 86077, Italy \\ ${ }^{7}$ Department of Pharmacy, University of Salerno, Fisciano 84084, Italy \\ ${ }^{8}$ Department of Medicine and Surgery, University of Salerno, Baronissi 84084, Italy \\ ${ }^{9}$ Pasteur Institute, Cenci-Bolognetti Foundation, Sapienza University of Rome, Rome 00185, Italy \\ ${ }^{10}$ Current address: Department of Hematology/Oncology and Stem Cell Transplantation, Bambino Gesù, 28 Children's \\ Hospital, IRCCS, Rome 00165, Italy \\ *These authors have contributed equally to this work \\ Correspondence to: Elisabetta Ferretti, email: elisabetta.ferretti@uniroma 1.it \\ Antonello Mai, email: antonello.mai@uniroma l.it \\ Keywords: histone methyltransferase, EZH2 inhibitors, hedgehog pathway, medulloblastoma stem-like cells, self-renewal \\ Received: November 18,2016 Accepted: June 20,2017 Published: August 02, 2017 \\ Copyright: Miele et al. This is an open-access article distributed under the terms of the Creative Commons Attribution License 3.0 \\ (CC BY 3.0), which permits unrestricted use, distribution, and reproduction in any medium, provided the original author and source \\ are credited.
}

\section{ABSTRACT}

The histone methyltransferase EZH2 plays a role in maintenance of the stem component of cancer, and its overexpression and/or mutation typically drives tumor aggressiveness, drug resistance and patients' poor prognosis. In this study, we use mouse and human medulloblastoma stem-like cells belonging to the Sonic Hedgehog subgroup (SHH MB-SLCs) and demonstrate that genetic suppression of EZH2 reduces the level of its histone mark $\mathrm{H} 3 \mathrm{K27} \mathrm{me} 3$ and lowers proliferation and self-renewal. We designed an EZH2 inhibitor (EZH2i) as a simplified analog of EPZ005687 and GSK2816126, MC3629, and we tested its biological activity in SHH MB-SLCs. Pharmacological inhibition of EZH2 impairs SHH MB cells proliferation and self-renewal, and induces apoptosis in vitro. Finally, we generated xenograft MB-SLCs orthotopic tumors in nude mice to test MC3629 in vivo. In treated mice, we observed impairment of tumor growth, together with induction of apoptosis and reduction of proliferation and stemness.

Overall, these findings describe EZH2 as a druggable target in MB and provide insight into the biological activity of MC3629 as an EZH2i.

\section{INTRODUCTION}

The histone methyltransferase (HMT) Enhancer of Zeste Homolog 2 (EZH2) is the catalytic subunit of the polycomb repressive complex 2 (PRC2) [1], which is responsible for methylation of histone $\mathrm{H} 3$ on lysine 27 up to its trimethylated form (H3K27me3) on the promoter region of target genes. EZH2/PRC2 induces an 
epigenetic change that regulates transcriptional silencing [2-4] and plays a pivotal role in different biological processes including differentiation, maintenance of cell identity and proliferation [5]. EZH2 overexpression and mutations occur in several malignancies [6] and are usually associated with aggressive tumors, drug resistance and poor prognosis [7-9].

As far as brain cancers, EZH2 expression increases with tumor grade in adult and pediatric tumors and it is a poor prognostic factor [10]. Medulloblastoma (MB) is the most common malignant pediatric brain tumor [11] and is among those tumors that overexpress EZH2 [12, 13]. EZH2 genetic or pharmacological targeting has been shown to impair MB cells growth [12].

Interestingly, EZH2 is known to sustain selfrenewal of cancer stem-like cells (SLCs) [14, 15]. In the hierarchical organization of tumor-cell populations envisioned by the cancer stem cell hypothesis, initiation, maintenance, and advancement of tumor growth are considered mainly properties of the SLCs compartment. Thus, EZH2-targeting drugs have become attractive weapons in cancer therapy [16] and research effort on developing enzymatic inhibitors is fueled [17]. Nevertheless, in vivo use of 3-deazaneplanocin A (DZNep) [18], a $S$-adenosyl-L-homocysteine (SAH) hydrolase inhibitor strongly effective against EZH2 in vitro, has been stopped because of toxicity in mice [19], and some catalytic $S$-adenosyl-L-methionine (SAM)-competitive EZH2 inhibitors (EZH2i) available for clinical use at the beginning of our study, such as EPZ005687 [20] and GSK2816126 [21], have a limitation for their use due to the poor bio-distribution in vivo and scarce ability to cross the blood brain barrier (BBB) [22, 23].

In this study we assessed the EZH2 expression and role in the SLCs derived from MB belonging to the Sonic Hedgehog (SHH) subgroup, namely SHH MBSLCs [11]. Having established the key function of EZH2 in this cellular context, we tested a simplified analog of EPZ005687 and GSK2816126 prepared by us, the $N$ ((4,6-dimethyl-2-oxo-1,2-dihydropyridin-3-yl)methyl)-5methyl-1-phenyl-1H-pyrazole-4-carboxamide MC3629, to determine its ability to target EZH2 and to impair $\mathrm{SHH}$ MB-SLCs in vitro and in vivo.

We show that either genetic or pharmacologic inhibition of EZH2 suppresses MB-SLCs, and in detail that MC3629 is able to impair MB proliferation/growth including its SLC compartment.

\section{RESULTS}

\section{Genetic inhibition of EZH2 impairs SHH MB cells proliferation and self-renewal}

We first assessed EZH2 protein levels in a series of MB cellular models including SHH MB-SLCs from both mouse models ( $\mathrm{Ptc}^{-/+}$mice) (mMB SLCs $\left.{ }_{1-3}\right)$ and human primary tumors $\left(\mathrm{hMB} \mathrm{SLCs} \mathrm{s}_{4-6}\right)$ that we had previously characterized [24].

We found high expression of EZH2 in both mouse and human MB-SLCs that grow as oncospheres in stem cell-medium (SM) and lower levels in cells grown in FBS-supplemented medium (DFM) (Figure 1A, left). In these conditions, MB-SLCs acquired a "differentiated" phenotype with adherent morphology, expressing both neuronal and glial lineage markers ( $\beta$ III-tubulin and GFAP, respectively) and reducing the expression of the stemness marker NANOG (Figure 1A). We also evaluated EZH2 levels in MB DAOY cells [25]. DAOY cells cultured for three days in SM, DAOY-SLCs, exhibited higher protein levels of EZH2 and NANOG, whereas they exhibited lower levels of $\beta$ III-tubulin and GFAP, when compared to DFM DAOY culture (Figure 1A).

First we tested three different lentiviral-mediated short hairpin silencing for $\mathrm{EZH} 2$ in both mouse and human MB-SLCs (Supplementary Figure 1A-1B), and then we used the most effective ones ( $\mathbf{a}$ and $\mathbf{d}$ clones, respectively) for further experiments in the three cellular models described above. ShEZH2-transduced DAOY cells showed decreased levels of H3K27me3 together with impairment of cell proliferation (Figure 1B, 1C and 1E). Moreover, in shEZH2-transduced MB-SLCs we observed reduced self-renewal capacity (Figure 1D and $1 \mathrm{~F})$.

To further validate our results, we sorted hMBSLCs for the CD133 stemness marker (Supplementary Figure 1C) [24] obtaining positive (CD133+) and negative (CD133-) hMB-SLCs fractions, that were transduced using lentiviral shEZH2. ShEZH2 impaired cell viability in CD133+ hMB-SLCs more significantly than in CD133hMB-SLCs (Supplementary Figure 1D).

Our results show that EZH2 plays a critical role in the maintenance of MB cells including SLCs.

\section{Pharmacologic inhibition of EZH2 with a pyrazole-based EZH2 inhibitor impairs SHH MB-SLCs cell viability}

EZH2 is a druggable target in different cancers [6], and commercial catalytic EZH2i, such as EPZ005687 and GSK2816126 (Figure 2A), are used in lymphoma with EZH2-activating mutations and also in solid tumors [20, 21, 26]. Nevertheless, there are reports regarding limitation to EZH2i use in vivo due to poor bio-distribution and scarce ability to cross the BBB $[22,23]$.

Following our researches on design, synthesis and biological evaluation of histone lysine methyltransferase inhibitors [27-32], we developed the pyrazole-based small molecule MC3629 as a simplified analog of EPZ005687 and GSK2816126. To design MC3629, we modified the 
A

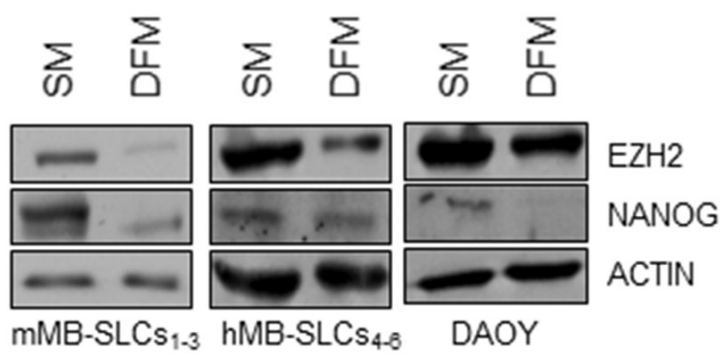

B

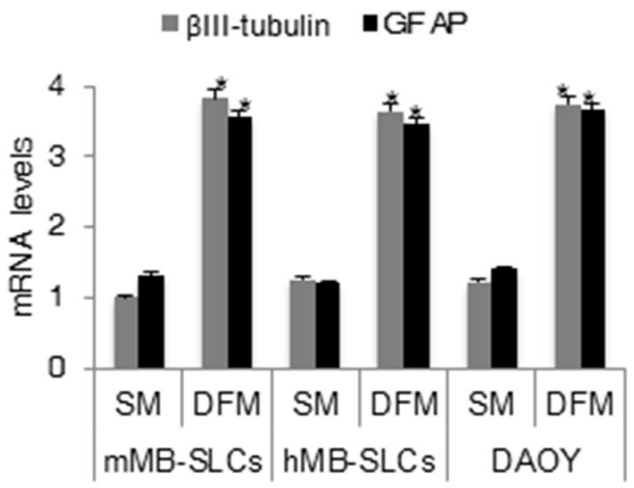

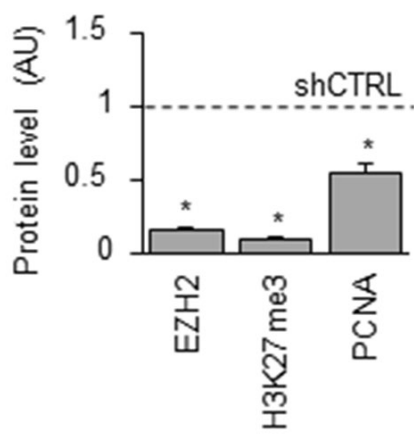

C

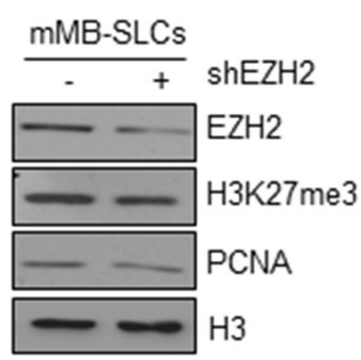

E

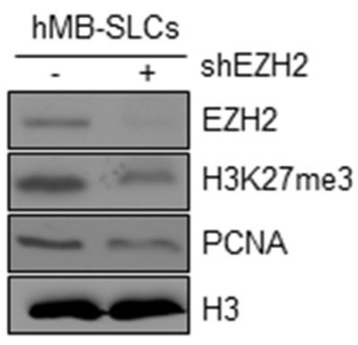

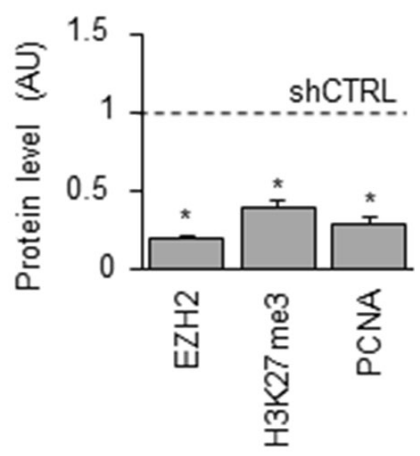

D

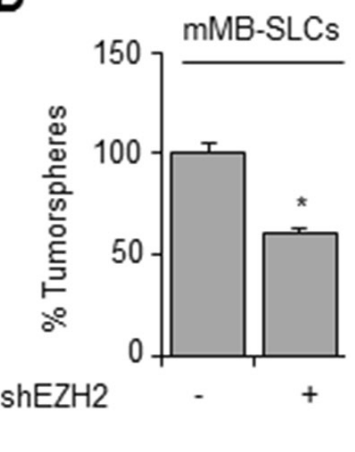

$\mathbf{F}$

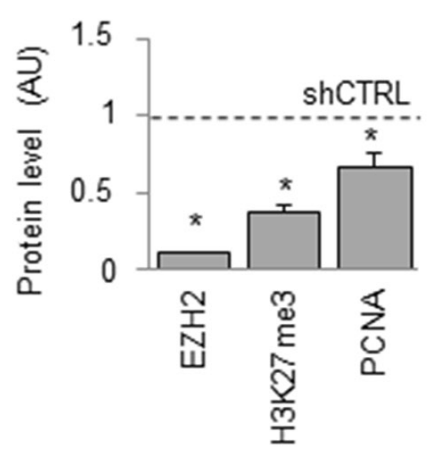

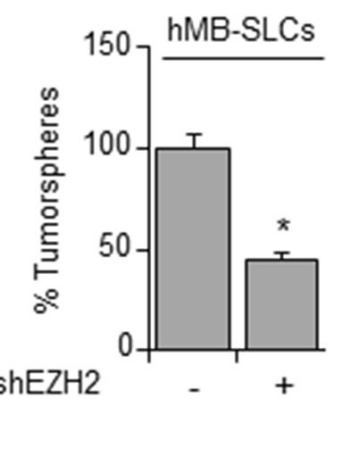

Figure 1: Genetic EZH2 knockdown impairs MB cell proliferation and self-renewal. (A) Left: representative Western Blot for EZH2 and NANOG protein levels in mMB-SLCs, hMB-SLCs and DAOY cells grown in SM and DFM. ACTIN was used as loading control. Right: mRNA levels of $\beta$ III-tubulin and GFAP of all the three models in SM and DFM. *p<0.05. (B-C-E) Left: representative Western Blot showing protein levels of EZH2, H3K27me3 and PCNA before and after shEZH2 in DAOY cells (B), mMB-SLCs (C) and hMB-SLCs (E). Dashed bars represent shRNA-non-target control (shCTRL). H3: loading control. Right: densitometric analysis of protein levels from three independent experiments. ${ }^{*} \mathrm{p}<0.05$. (D-F) Self-renewal ability (percentage of tumorspheres) of mMB-SLCs and hMBSLCs after shEZH2 or shCTRL. *p $<0.05$. 
A<smiles>C=C=CCn1ncc2c(C(=O)NCc3c(C)cc(C)[nH]c3=O)cc(-c3ccc(CN4CCOCC4)cc3)cc21</smiles>

EPZ005687

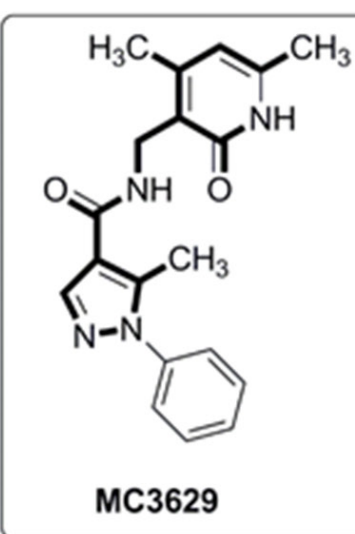<smiles>C=C=C[R16](=O)[Sb]</smiles>

B

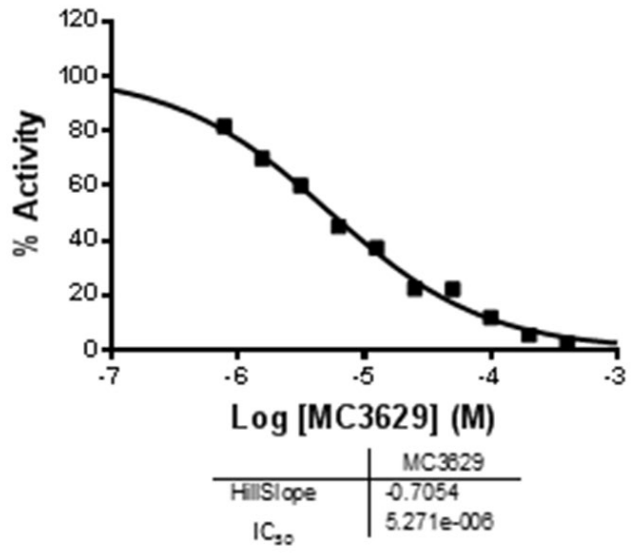

D

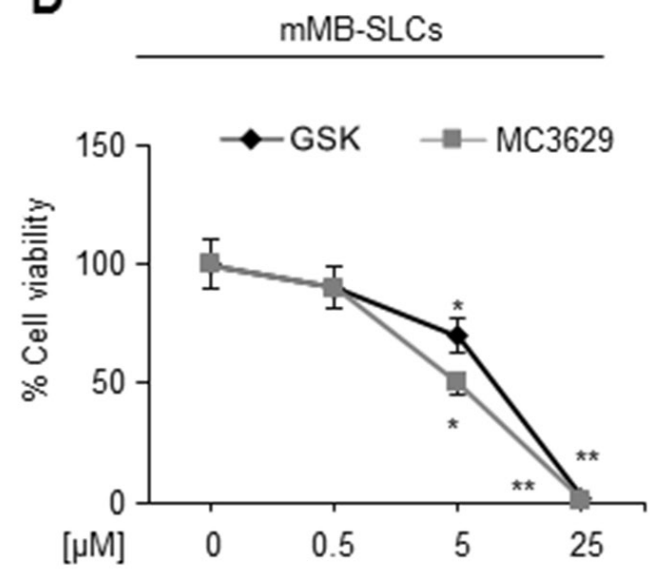

C

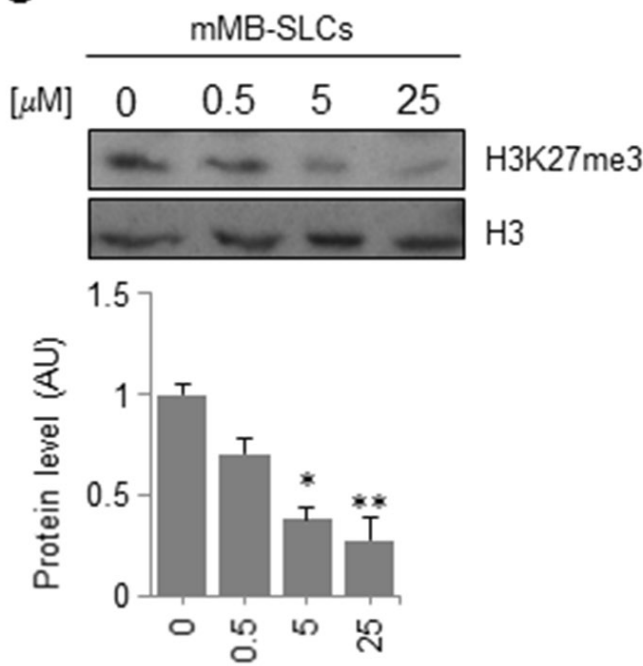

E

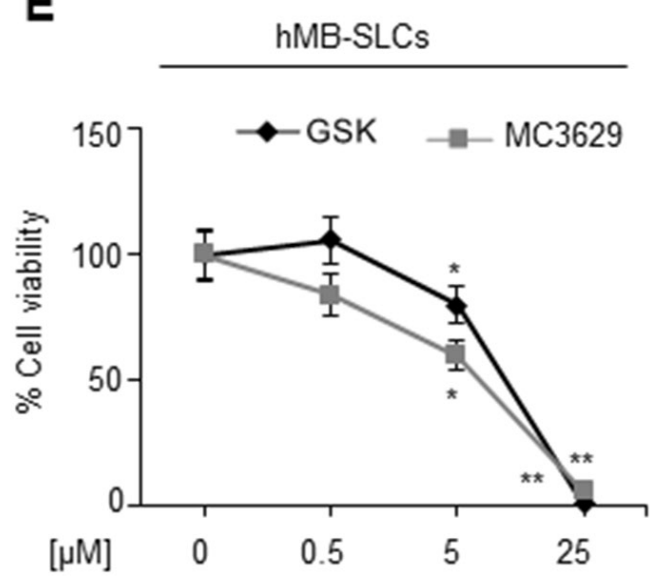

Figure 2: The EZH2 inhibitor MC3629 impairs SHH MB-SLCs viability. (A) Design of MC3629 starting from modification of the EPZ005687 and GSK2816126 structures. (B) EZH2/PRC2 assay in 10-dose IC $_{50}$ mode with 2-fold serial dilution starting from 400 $\mu \mathrm{M}$ solution. Histone H3/H4 tetramer was used as the substrate. (C) Representative Western Blot (up) and densitometric analysis (down) of H3K27me3 protein levels in mMB SLCs treated for $48 \mathrm{~h}$ with $0.5,5$ and $25 \mu \mathrm{M}$ of MC3629. $* \mathrm{p}<0.05$, $* * \mathrm{p}<0.01$. (D-E) Evaluation of cell viability, measured with MTS assay, of mMB-SLCs (D) and hMB-SLCs (E) treated with increasing concentrations of MC3629 and GSK2816126 at 48 h. $p$ value versus untreated cells: ${ }^{*} p<0.05,{ }^{*} p<0.01$. 
structure of these two known EZH2i removing the benzene ring from the indazole or indole nucleus, respectively, to obtain a monocyclic nitrogen-containing heteroaromatic ring (the pyrazole ring) linked through a carboxamide function to the 3-aminomethyl-4,6-dimethyl-2-pyrimidone moiety, known to be crucial for EZH2 inhibition (Figure 2A) [33]. The synthesis of MC3629, as well as its physical and chemical data, are reported in Supplementary Materials - Chemistry.

MC3629 was tested in the cell free enzymatic assay (EZH2/PRC2) in 10-dose $\mathrm{IC}_{50}$ mode with 2-fold serial dilution starting from $400 \mu \mathrm{M}$ solution, using various histone substrates (histone $\mathrm{H} 3 / \mathrm{H} 4$ octamer, histone $\mathrm{H} 3 / \mathrm{H} 4$ tetramer, histone $\mathrm{H} 3$, and core histone) and SAM as the co-substrate. In these assays, MC3629 displayed $\mathrm{IC}_{50}$ values in the range 5.27-15.4 $\mu \mathrm{M}$, with GSK2816126 used as a reference drug $\left(\mathrm{IC}_{50}=\right.$ $9.13 \mathrm{nM}$ (core histone substrate), according to the literature) [22] (Figure 2B, and Supplementary Figure 2). SAM competition experiments using histone $\mathrm{H} 3$ / H4 octamer as the substrate confirmed its SAMdependent mechanism of inhibition (Supplementary Figure 3). The percentages of inhibition by MC3629, used at $200 \mu \mathrm{M}$, towards a panel of methyltransferases including lysine (EZH1 complex, DOT1L, G9a, MLL1 complex, SET7/9), arginine (PRMT1) and DNA (DNMT1) methyltransferases definitively showed that the inhibition activity of MC3629 is selective for EZH2/ PRC2 (Supplementary Table 1).

Afterwards, we tested the ability of MC3629 (at 0.5, 5 , and $25 \mu \mathrm{M}$ ) to inhibit the EZH2 enzymatic activity on a cell-based assay in vitro. The lower significant MC3629 dosage to decrease the H3K27me3 level in MB-SLCs was $5 \mu \mathrm{M}$ (Figure 2C).

Next, we assessed the biological effects of MC3629 on MB-SLCs by dose- and time-dependent experiments, using GSK2816126 as a reference drug. In both cell lines, we determined the lowest useful dose of MC3629 $(5 \mu \mathrm{M})$ and the minimum effective time (48 h) (Figure 2D, 2E and Supplementary Figure 4A and 4B for data at 24 and $72 \mathrm{~h}$ ). We next evaluated the performance of MC3629 on MB-SLCs in terms of cell viability in regards to other $\mathrm{EZH} 2 \mathrm{i}$ in use, confirming the dose selection (Supplementary Figure 4C).

To test the specificity of the pyrazole-based EZH2 inhibitor we combined the genetic and pharmacological inhibition of EZH2 on hMB-SLCs evaluating the corresponding cell viability (Supplementary Figure 5A). In our MB-SLC the combination of MC3629 (5 $\mu \mathrm{M})$ with shEZH2 did not display any additive effect in respect to the shEZH2 treatment alone.

To rule out nonspecific toxic effects by MC3629, we tested the EZH2i on neural stem cells (NSC) as a model of non-transformed cells [24], and we did not observe any effects on H3K27me3 and PCNA protein levels (Supplementary Figure 5B).

\section{Pharmacological inhibition of EZH2 impairs SHH MB cells proliferation and self-renewal, and induces apoptosis}

We analyzed the biological effects of MC3629 treatment in mMB-SLCs and hMB-SLCs using GSK2816126 as a reference drug. As shown in Figure $3 \mathrm{~A}$ and $3 \mathrm{~B}$, both EZH2i significantly impaired H3K27me3 and PCNA protein levels, and MC3629 induced apoptosis, detected as increased level of cleaved caspase 3. Furthermore, we investigated whether the two compounds were able to impair stemness, both MC3629 and GSK2816126 significantly reduced mMB-SLC and hMB-SLC self-renewal (Figure 3C and 3D).

We then tested the effects of MC3629 and GSK2816126 in DAOY and DAOY-SLCs. In DAOY cells, H3K27me3 and PCNA levels resulted impaired only by MC3629 (Figure 4A). In DAOY-SLCs, H3K27me3 and PCNA levels were down modulated by both drugs (Figure 4A). Such effects were confirmed in DAOY cells and DAOY-SLCs: MC3629 impaired cell viability in both cell systems after $48 \mathrm{~h}$, while GSK2816126 was able to significantly impair DAOY-SLCs viability after $72 \mathrm{~h}$ of treatment (Figure 4B). Moreover, MC3629 induced cell death in DAOY-SLCs (Figure 4C).

Altogether, our results show that EZH2 pharmacological inhibition is able to impair MB cells proliferation and stemness, and induce apoptosis.

\section{MC3629 impairs SHH MB-SLCs growth and stemness in vivo}

First, we tested both MC3629 and GSK2816126 in the parallel artificial membrane permeability assay for the BBB (PAMPA-BBB), to measure the effective permeability $(\mathrm{Pe}, \mathrm{cm} / \mathrm{s})$ of MC3629 through a porcine brain lipid (PBL) extract impregnated on a solid filter support, used as an artificial lipid membrane [34]. Propranolol and furosemide were used as positive and negative controls, respectively. In this assay, MC3629 displayed a closer capability to permeate the lipid membrane to propranolol than GSK2816126, as highlighted by the $\Delta$ values (Table 1 and Supplementary Figure 6).

Dose finding experiments showed that twice/week intra-peritoneal injection of MC3629 at $20 \mu \mathrm{Mol} / \mathrm{Kg}$ led to a significant reduction of $\mathrm{H} 3 \mathrm{~K} 27 \mathrm{me} 3$ levels in the cerebella of 6-day-old mice (Supplementary Figure 7A). At this dose, we observed reduced levels of H3K27me3 not only in cerebellum but also in brain (Figure 5A), indicating that MC3629 crosses the BBB. 
A

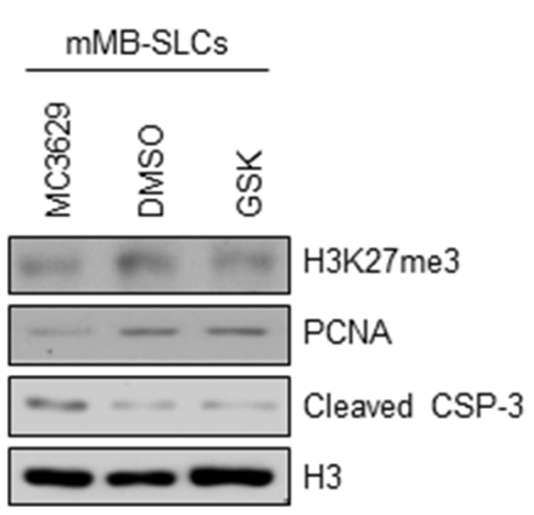

B
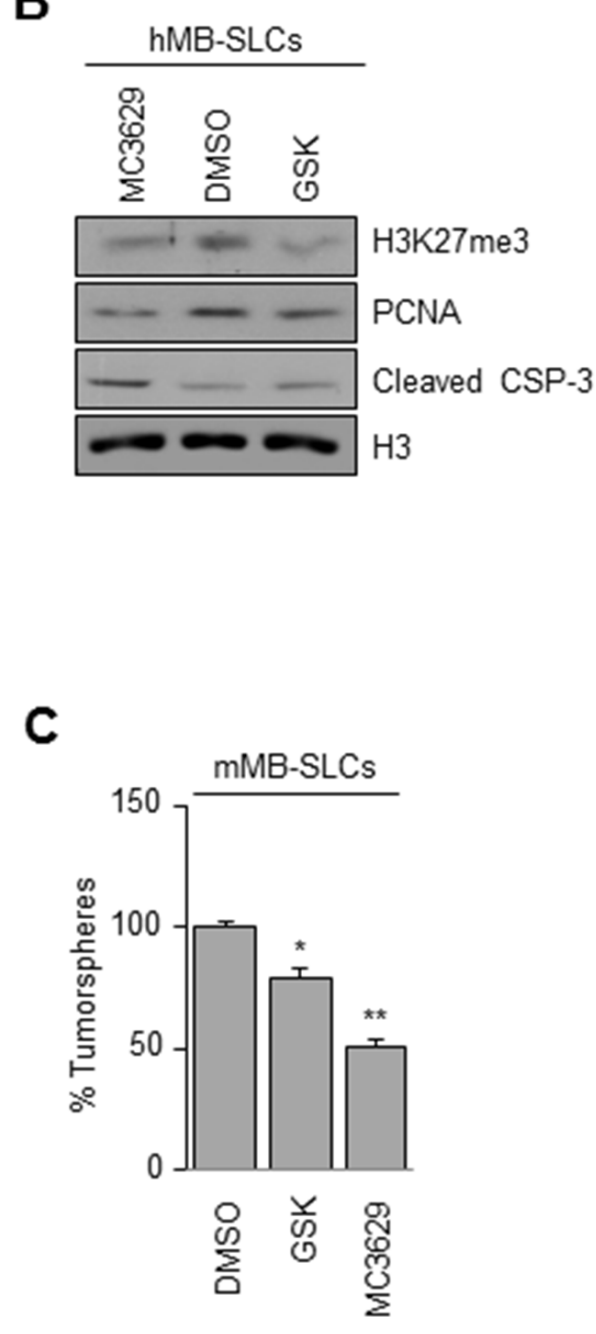

$\square$ GSK

$\square$ MC3629

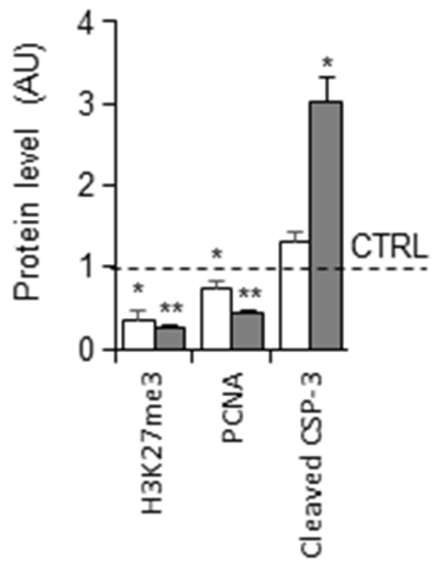

$\square$ GSK

MC3629

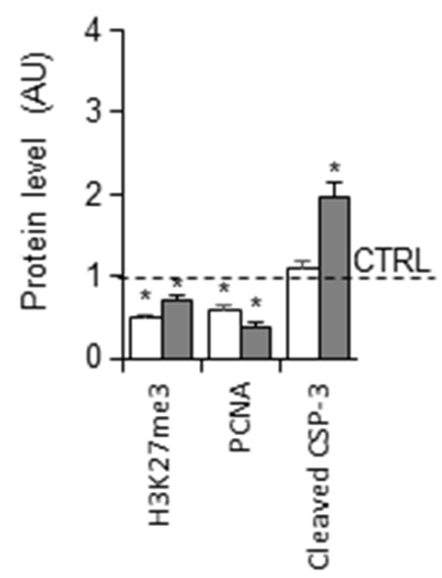

D

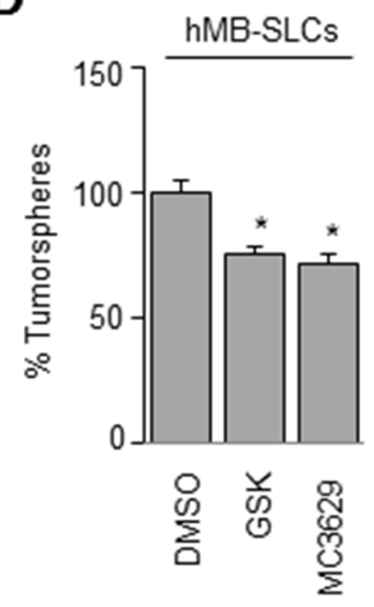

Figure 3: Biological effects of EZH2 inhibition in SHH MB-SLCs. (A-B) mMB-SLCs and hMB-SLCs were treated for $48 \mathrm{~h}$ with $5 \mu \mathrm{M}$ of MC3629 or GSK2816126. Representative images of Western Blot (left) and densitometric analysis (right) of H3K27me3, PCNA, and cleaved caspase 3 (cleaved CSP-3). H3: loading control. Dashed bars represent DMSO-treated cells (CTRL). ${ }^{*} p<0.05$, ${ }^{* *} p<0.01$. (C-D) Self-renewal measured by clonogenic assay. ${ }^{*} \mathrm{p}<0.05,{ }^{*} \mathrm{p}<0.01$. 
A

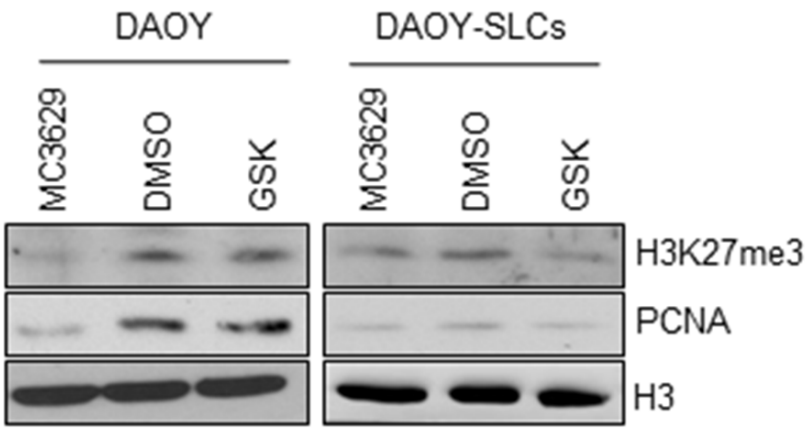

B

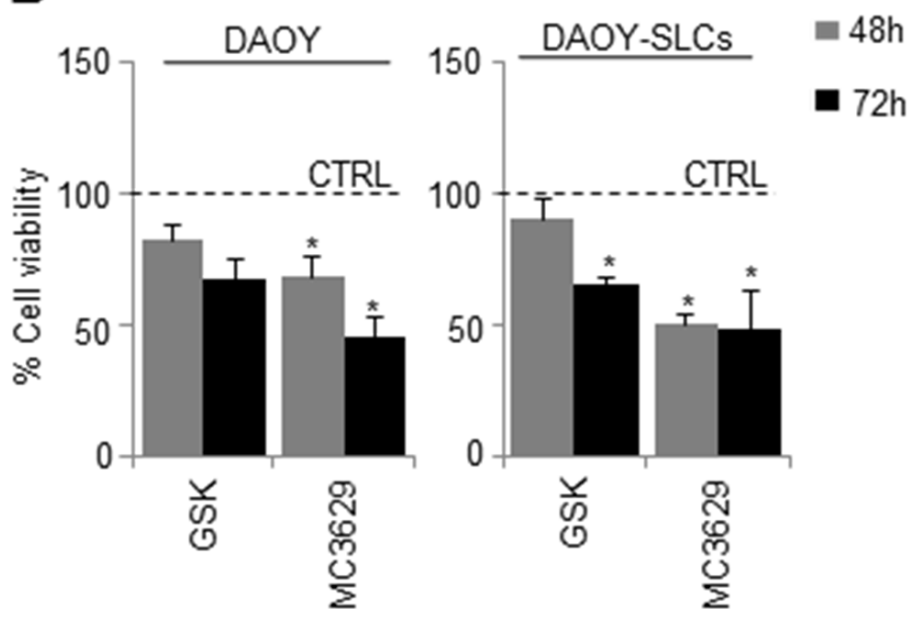

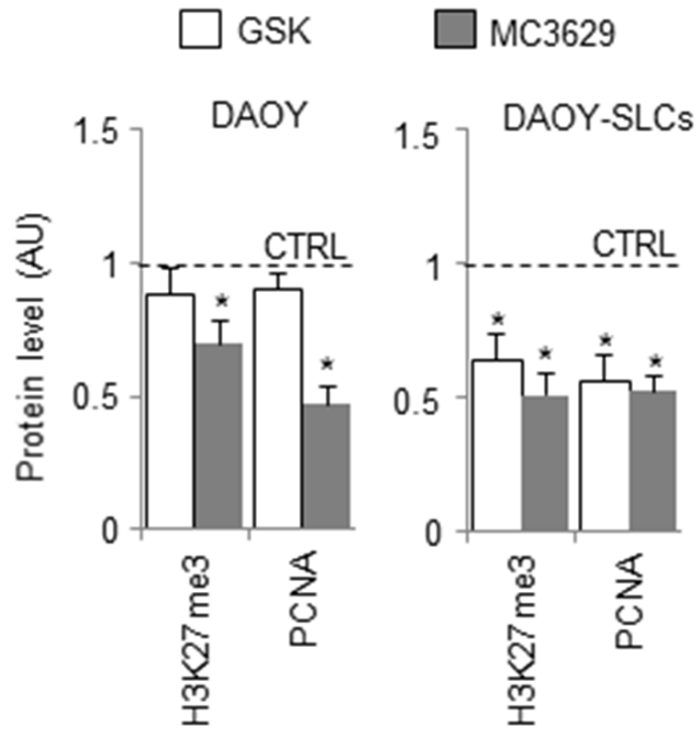

C

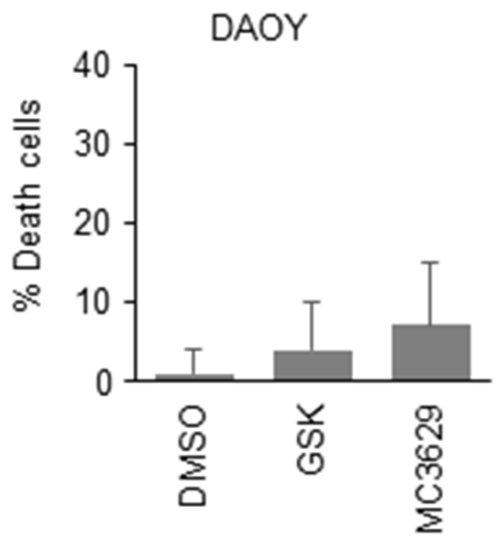

DAOY-SLCS

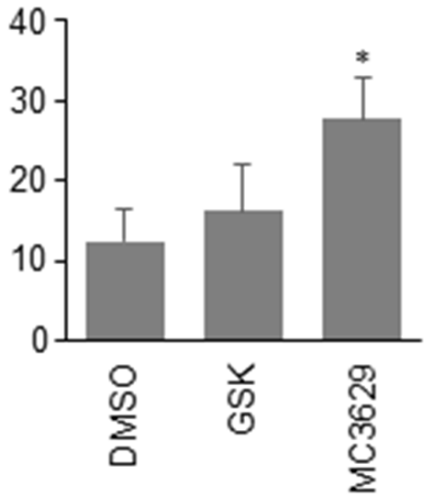

Figure 4: Biological effects of EZH2 inhibition in DAOY cells and DAOY-SLCs. (A) DAOY cells and DAOY-SLCs were treated for $48 \mathrm{~h}$ with $5 \mu \mathrm{M}$ of MC3629 or GSK2816126. Representative images of Western Blot (left) and densitometric analysis (right) of H3K27me3 and PCNA. H3: loading control. Dashed bars represent DMSO-treated cells (CTRL). *p<0.05. (B) Evaluation of cell viability, measured with MTS assay, of DAOY and DAOY-SLCs treated for $48 \mathrm{~h}$ and $72 \mathrm{~h}$ with $5 \mu \mathrm{M}$ of MC3629 or GSK2816126. *p $<0.05$. (C) Percentage of cell death assessed in DAOY and in DAOY-SLCs treated with both compounds for $72 \mathrm{~h}$. Bars represent the mean of at least three independent experiments performed in triplicate mean \pm S.D. ${ }^{*} \mathrm{p}<0.05$. 
Table 1: Log Pe values of tested compounds in the PAMPA-BBB

\begin{tabular}{lcc}
\hline COMPOUND & Log $\mathbf{P}_{\mathrm{e}}$ & $\Delta *$ \\
\hline GSK2816126 & $-5.41 \pm 0.04$ & -0.20 \\
MC3629 & $-5.33 \pm 0.01$ & -0.12 \\
propranolol (positive control) & $-5.21 \pm 0.06$ & \\
furosemide (negative control) & under detection limit & \\
\hline
\end{tabular}

*Respect to propranolol.

Next, we generated xenograft DAOY-SLCs orthotopic tumors (XT-MB) in nude mice that grew as tumor masses with the characteristics of MBs.

Mice treatment with MC3629 significantly impaired XT-MB growth (Figure 5B), and Western Blot analysis of tumor xenografts revealed a reduction of $\mathrm{H} 3 \mathrm{~K} 27 \mathrm{me} 3$ in treated mice (Figure 5C). Interestingly, tumors from treated mice also showed significantly lower levels of NANOG protein (Figure 5C), and a significant reduction of proliferating Ki67-positive cells as well (Figure 5D).

Finally, we observed induction of apoptosis, detected as increased level of cleaved caspase 3 in treated mice (Supplementary Figure 7B).

Taken together, these data show that MC3629 is effective in hampering MB-SLCs growth in vivo.

\section{DISCUSSION}

Epigenetic alterations have been shown to be important in cancer initiation and progression [12, 13, 35]. Among these, histone $\mathrm{H} 3 \mathrm{~K} 9$ and $\mathrm{H} 3 \mathrm{~K} 27$ methylation play a key role in cancer due to their association with gene silencing [36-39].

Based on the EZH2 role in tumorigenesis and stem cell maintenance, studies have been focused on targeting EZH2, a H3K27 methyltransferase, as a novel cancer treatment, and aimed to identify small molecules that inhibit its catalytic activity [5, 6, 40-42].

Recently, several groups reported compounds (e.g. GSK2816126, EPZ005687, EPZ6438, E11, UNC1999 and the second generation drug tazemetostat) that directly and selectively inhibit the EZH2/PRC2 enzymatic activity [17, 42, 43]. Among them, GSK2816126 is characterized by high and selective biochemical and cellular on-target potency, assessed by decrease in H3K27 trimethylation levels, has been validated in preclinical studies for treatment of lymphoma with EZH2-activating mutations [21], and is actually in phase I clinical trial for the treatment of lymphomas, solid tumors and multiple myeloma (https://clinicaltrials.gov/ct2/results?term=GSK 2816126\&Search=Search).

In $\mathrm{MB}$ cells, pharmacological inhibition of EZH2 was achieved by the use of DZNep, an inhibitor of SAH hydrolase that inhibits EZH2 through an indirect way [12]. Nevertheless, this compound displays poor EZH2 selective inhibition [44] and is not in clinical use due to its toxicity [19].

With this study, we tested the biological activity of the catalytic EZH2 inhibitor MC3629, designed and prepared by us as a simplified analog of EPZ005687 and GSK2816126, in the SHH MB cancers cells and SLCs.

In MB-SLCs derived in our laboratory from patients affected by $\mathrm{SHH}$ MB or from SHH MB murine model, the genetic silencing of EZH2 led to reduction of $\mathrm{H} 3 \mathrm{~K} 27 \mathrm{me} 3$ levels, reduction of proliferation, and self-renewal impairment.

In the same cellular models, we tested MC3629 using GSK2816126 as a reference drug. MC3629 at 5 $\mu \mathrm{M}$ displayed significant biological activity impairing cell proliferation and self-renewal, and inducing apoptosis. When co-administered with shEZH2 to hMBSLCs, MC3629 did not show any additive effect on cell viability, thus confirming its selective action on the methyltransferase target.

Prompted by our results, we tested MC3629 in PAMPA-BBB assay to ascertain its capability to cross BBB in vitro. Moreover, we observed the ability of MC3629 to reduce H3K27me3 levels in brain and cerebellum in vivo. Finally, we treated MB xenografted mice with MC3629, to extend its biological activity in vivo. By this set of experiments, we observed a significant decrease of tumor volume, a reduction of stemness and cell proliferation, and induction of apoptosis in treated mice.

Overall, in this study we validated EZH2 as an attractive target for $\mathrm{SHH} \mathrm{MB}$ cancer and cancer stem cell impairment, and showed that EZH2 pharmacological inhibition exerted by MC3629 is effective in MB cells and in MB xenografted mouse models. 
A
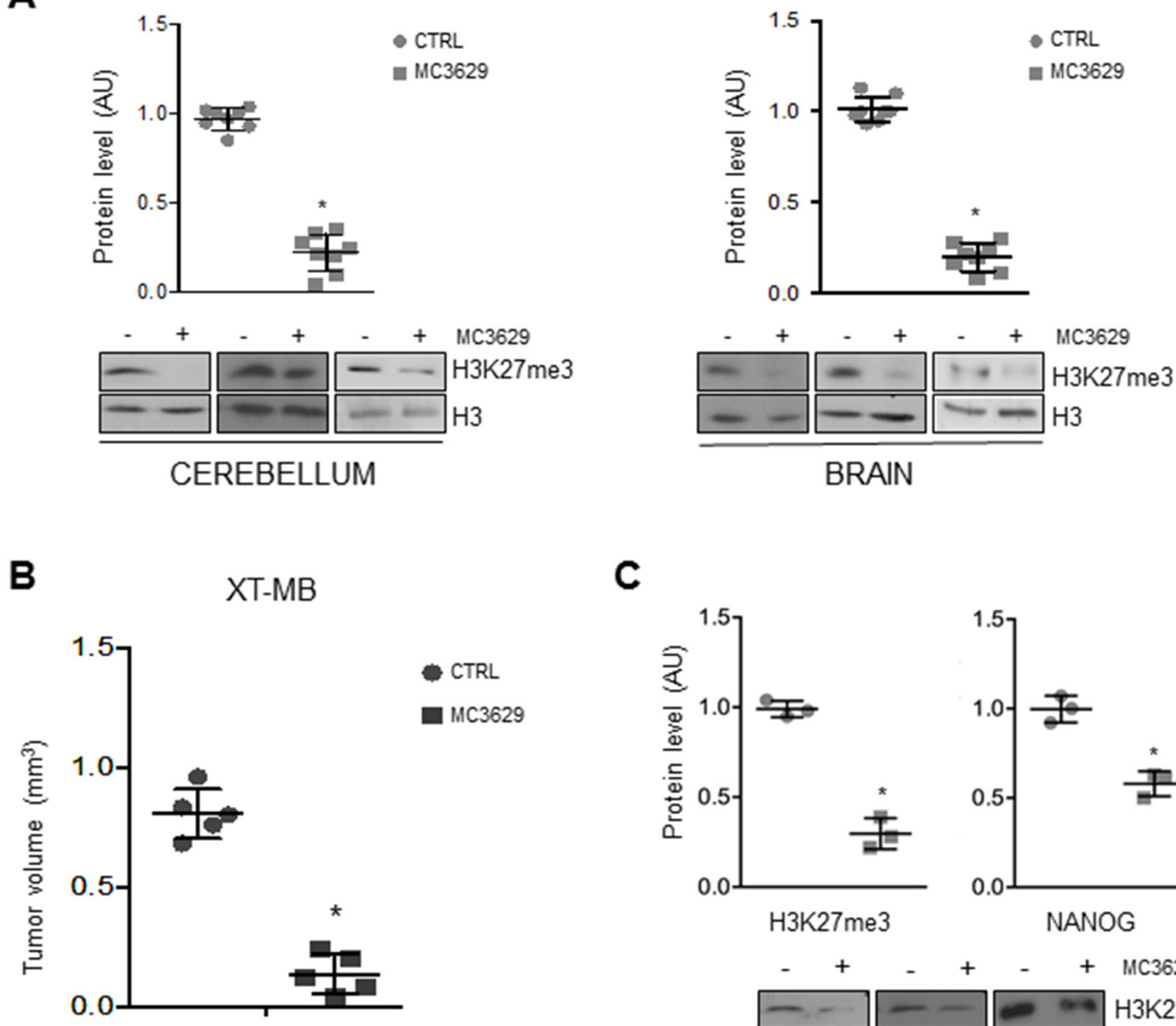

C

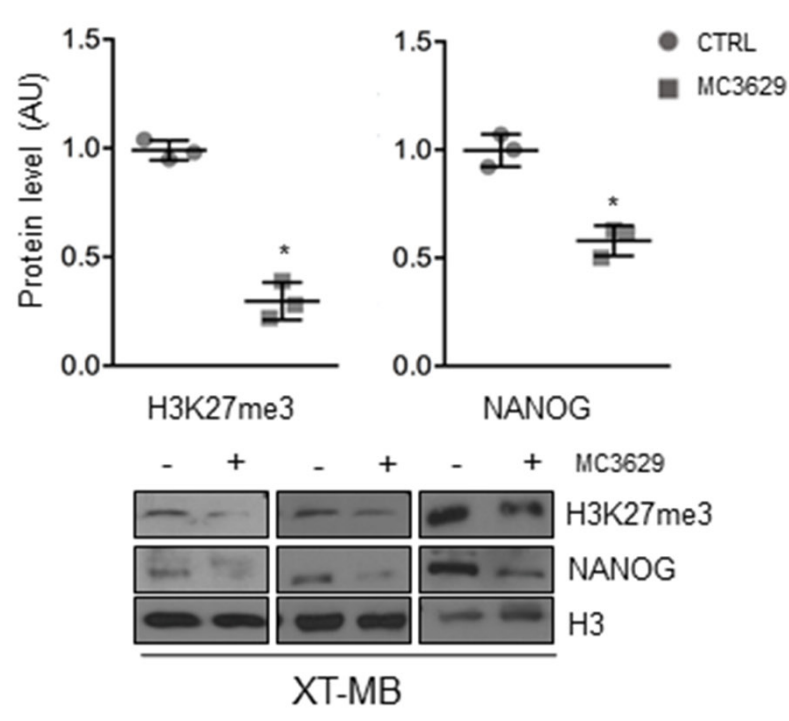

D
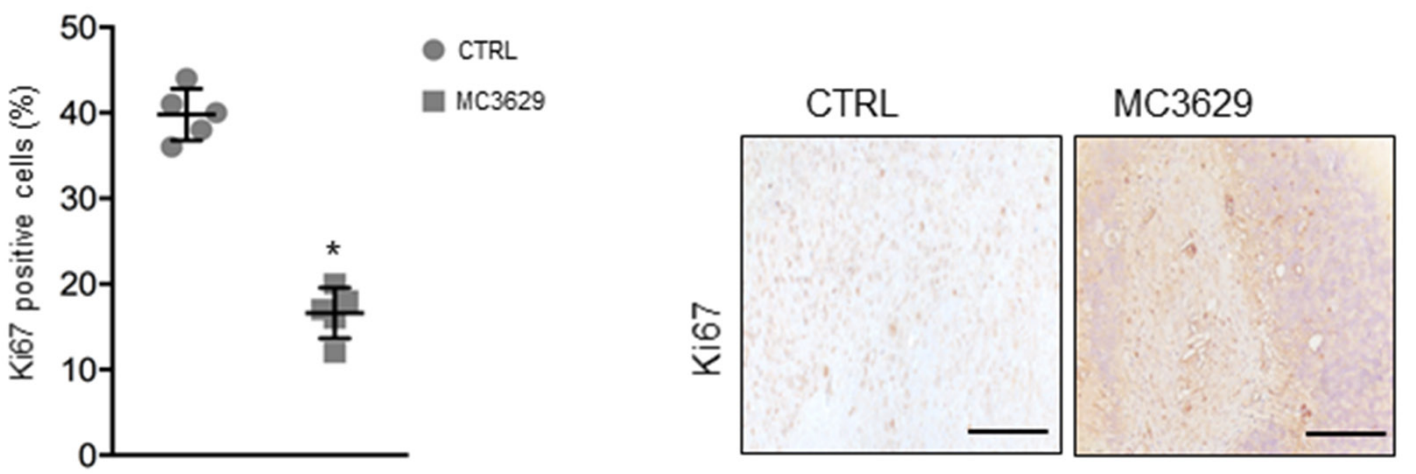

Figure 5: Biological effects of MC3629 in vivo. (A) Representative Western Blots show H3K27me3 levels in cerebellum and brain from wild type mice treated with MC3629 or vehicle (CTRL). Dot plots represent densitometric analysis of all samples. *p $<0.05$. (B-D) Xenograft tumors (XT-MB) were generated in mice, after 10 days MC3629 was administered twice a week for 3 weeks; control mice were treated with vehicle (CTRL). (B) Xenograft volume $\left(\mathrm{mm}^{3}\right)$ evaluated at the maximum diameter; dot plot represents mean \pm S.D. $* p<0.05$. (C) Representative images of Western Blot and densitometric analysis of H3K27me3 and NANOG. H3: loading control *p<0.05. (D) Xenograft sections were immunostained for the proliferation marker Ki67: on the left, dot plot shows Ki67 levels of proliferating cells; on the right, representative images of the staining. ${ }^{*} p<0.05$. 


\section{MATERIALS AND METHODS}

\section{Drug synthesis}

The synthetic procedure to prepare MC3629 as well as its physical, chemical and spectral data are reported in Supplementary Materials - Chemistry.

\section{EZH2 assay}

Reagents: Reaction buffer; $50 \mathrm{mM}$ Tris- $\mathrm{HCl}$ (pH 8.0), $50 \mathrm{mM} \mathrm{NaCl}, 1 \mathrm{mM}$ EDTA, $1 \mathrm{mM}$ DTT, 1 mM PMSF, 1\% DMSO. Reaction Conditions: EZH2: Complex of human EZH2 (GenBank Accession No. NM_004456), (amino acids 2-end) with $N$-terminal His tag, MW= $86 \mathrm{kDa}$, human EED (NM_003797) (a-a 2-end) with $N$-terminal Flag tag, MW= $51 \mathrm{kDa}$, human SUZ12 (NM 015355) (a-a 2-end) with $N$-terminal His tag, MW $=87 \mathrm{kDa}$, Human AEBP2 (NM_153207) (a-a 2-end) with $N$-terminal His tag, $\mathrm{MW}=53 \mathrm{kDa}$, and human RbAp48 (NM_005610) (a-a 2-end) with $N$-terminal His tag, MW $=48 \mathrm{kDa}$, co-expressed in baculovirus expression system. Substrate: $5 \mu \mathrm{M}$ histone $\mathrm{H} 3 / \mathrm{H} 4$ tetramer. Methyl donor: $1 \mu \mathrm{M} S$-adenosyl-L-[methyl- $\left.{ }^{3} \mathrm{H}\right]$ methionine $\left({ }^{3} \mathrm{H}-\mathrm{SAM}\right)$. Enzyme: 100 nM EZH2 complex. Reaction Procedure: the indicated substrate was dissolved in freshly prepared Reaction Buffer; EZH2 was delivered into the substrate solution and mixed gently. The compound was dissolved in DMSO to a stock of $20 \mathrm{mM}$ and was tested in a 10-dose $\mathrm{IC}_{50}$ mode with 2-fold serial dilution starting at $400 \mu \mathrm{M}$. The compound was delivered in DMSO into the EZH2 reaction mixture by using Acoustic Technology (Echo 550, LabCyte Inc. Sunnyvale, CA) in nanoliter range, and incubated for $15 \mathrm{~min} ;{ }^{3} \mathrm{H}-\mathrm{SAM}$ was delivered into the reaction mixture to initiate the reaction; the reaction mixture was incubated for $1 \mathrm{~h}$ at $30^{\circ} \mathrm{C}$ and then delivered to filter-paper for detection; data were analyzed using Excel and GraphPad Prism 5 software for $\mathrm{IC}_{50}$ curve fits. For SAM competition experiments, the same procedure was used with different SAM concentration $(1,2.5 .5$, and $10 \mu \mathrm{M})$ and $\mathrm{H} 3 / \mathrm{H} 4$ octamer as the substrate.

\section{EZH1 complex, DOT1L, G9a, MLL1 complex, SET7/9, PRMT1, and DNMT1 assays}

The appropriate methyltransferase (MT) substrate $(0.05 \mathrm{mg} / \mathrm{ml}$ core histone for EZH1 complex, $0.05 \mathrm{mg} /$ $\mathrm{ml}$ oligonucleosomes for DOT1L, $5 \mu \mathrm{M}$ histone H3 (121) peptide for $\mathrm{G} 9 \mathrm{a}, 0.05 \mathrm{mg} / \mathrm{ml}$ nucleosomes for MLL1 complex, $0.05 \mathrm{mg} / \mathrm{ml}$ core histone for SET7/9, $5 \mu \mathrm{M}$ histone H4 for PRMT1, and $0.001 \mathrm{mg} / \mathrm{ml}$ poly $(\mathrm{dI}-\mathrm{dC})$ for DNMT1) was added in freshly prepared Reaction Buffer (50 mM Tris- $\mathrm{HCl}(\mathrm{pH} 8.5), 5 \mathrm{mM} \mathrm{MgCl}, 50 \mathrm{mM} \mathrm{NaCl}$, $0.01 \%$ Brij35, $1 \mathrm{mM}$ DTT, $1 \%$ DMSO). The MT enzyme was delivered into the substrate solution and the mixture was mixed gently. Afterwards, the tested compound dissolved in DMSO was delivered into the enzyme/ substrate reaction mixture by using Acoustic Technology (Echo 550, LabCyte Inc. Sunnyvale, CA) in nanoliter range, and $1 \mu \mathrm{M}{ }^{3} \mathrm{H}-\mathrm{SAM}$ was also added into the reaction mixture to initiate the reaction. The reaction mixture was incubated for $1 \mathrm{~h}$ at $30{ }^{\circ} \mathrm{C}$ and then it was delivered to filter-paper for detection. The data were analyzed using Excel and GraphPad Prism software for $\mathrm{IC}_{50}$ curve fits (for EZH1 complex).

\section{Cell culture}

DAOY cells were obtained from ATCC and cultured in MEM medium (Gibco, Invitrogen), supplemented with $10 \%$ heat-inactivated fetal bovine serum, $1 \%$ sodium pyruvate, $1 \%$ non-essential amino acid solution, $1 \%$ L-glutamine and penicillin/streptomycin. Human and mouse stem-like cells (hMB-SLC and mMB-SLC) were derived, as previously described from primary human SHH-MBs and from spontaneous tumors arisen in $\mathrm{Ptc}^{+/-}$ mice [24]. DAOY-SLCs were obtained as described in Alimova et al., 2012 [12].

All SLCs were maintained in DMEM/F12 supplemented with $0.6 \%$ glucose, $25 \mathrm{mg} / \mathrm{ml}$ insulin, 60 $\mathrm{mg} / \mathrm{ml} N$-acetyl-L-cystein, $2 \mathrm{mg} / \mathrm{ml}$ heparin, $20 \mathrm{ng} / \mathrm{ml}$ EGF, 20 ng/ml bFGF (Peprotech, Rocky Hill, NJ), 1X penicillin-streptomycin and B27 supplement without vitamin A (Gibco).

For differentiation experiments, hMB-SLCs and mMB-SLC were mechanically dissociated and plated for $48 \mathrm{~h}$ on D-poly-lysine coated dishes in differentiation medium (DMEM/F12 with $\mathrm{N}_{2}$ supplement and $2 \mathrm{mg} / \mathrm{ml}$ heparin, $0,6 \%$ glucose, $60 \mathrm{mg} / \mathrm{ml} N$-acetyl-L-cysteine, $1 \%$ FBS).

For self-renewal assessment, clonogenic assay was performed as previously described [24]. Briefly: oncospheres were disaggregated with non-enzymatic cell dissociation buffer (Sigma) and cells were plated at clonal density (1-2 cells $\left./ \mathrm{mm}^{2}\right)$ into 96-well plates and cultured for an appropriate number of days (7-15) until oncospheres were countable.

\section{Infection, treatments and cell viability assay}

For lentiviral-transduction of specific antiEZH2, short hairpins lentiviral particles were purchased from Sigma: MISSION shRNA-non-target control Transduction Particles (SCH002V); three human Lenti ShEZH2: MISSION shRNA EZH2 Lentiviral (SHCLNV) Clones TRCN0000010475, TRCN0000040074 and TRCN0000040077; three murine Lenti ShEZH2: MISSION shRNA EZH2 Lentiviral Clones TRCN0000304505, TRCN0000039041 and TRCN0000039042. Clone TRCN0000010475 for human and Clone TRCN0000304505 for mouse were used for the experiments since they demonstrated the best knock-down efficency with less off-target; cells were infected for $48 \mathrm{~h}$. 
Unless otherwise specified, cells were treated for 48 $\mathrm{h}$ with either GSK2816126 (Selleckchem) or MC3629 at 5 $\mu \mathrm{M}$. To evaluate cell viability cells were plated at a density of $5 \times 10^{3}$ cells/well in 96-well plates and were incubated with MTS solution (CellTiter 96® AQueous One Solution Promega).

\section{Fluorescence-activated cell sorting}

Cells were sorted based on CD133 expression levels using a FACSAriaIII (BD Biosciences) equipped with a $633 \mathrm{~nm}$ laser and FACSDiva software (BD Biosciences version 6.1.3). Briefly, cells were immunostained with APC-conjugated anti-CD133 (Miltenyi Biotec) according to manufacturer's protocol, and were then subjected to cell sorting. Cells were gated using forward and side scatter (FSC-A and SSC-A) plot to identify live cells (average $65 \%$ ), and were then detected in the APC channel for CD133 expression. Following this gate strategy, cells were sorted for expression of CD133 (APC- and APC+ cells) and subsequently checked for purity.

\section{Trypan blue test}

Trypan blue exclusion test was used to count viable or death cells present in a cell suspension [45]. Each sample was measured in triplicate and repeated at least three times.

\section{Western blot}

Western blots were performed according to standard procedures [46]. Briefly, protein lysates were prepared using RIPA buffer with fresh protease inhibitors. Lysates were separated on SDS polyacrylamide gels. Proteins were transferred on nitrocellulose membrane $(0.45$ micron) (PerkinElmer). Membranes were blocked for $1 \mathrm{~h}$ at room temperature in 5\% nonfat dry milk and incubated overnight at $4{ }^{\circ} \mathrm{C}$ with antibodies against EZH2 (4905S Cell signaling), H3K27me3 (07-449 Millipore), PCNA (2586 Cell signaling), ACTIN (I-19 sc-1616; Santa Cruz Biotechnology), GAPDH (ab9484, Abcam), cleaved CSP-3 (D-175 9661S; Cell Signaling) and H3 (ab1971, Abcam). HRP-conjugated secondary antibodies (Santa Cruz Biotechnology) were used in combination with enhanced chemiluminescence (ECL Amersham).

\section{RNA extraction and quantitative real-time PCR}

RNA was isolated from cells using TriReagent (Ambion) and retro transcribed using the High Capacity cDNA Reverse Transcription kit (Thermo Scientific). cDNAs were analyzed using the ViiA ${ }^{\mathrm{TM}} 7$ Real-Time PCR System (Thermo Scientific) SensiFAST TM Probe LoROX (Bioline), and TaqMan gene expression assays for $\beta$ IIITubulin (Hs-00801390_s1, Mm00727586_s1) and GFAP (Hs-00909233_m1, Mm01253033_m1) for human and mouse respectively. Results were evaluated using the 2- $\triangle \Delta \mathrm{CT}$ method and mRNA quantification was normalized to 2 endogenous controls: ACTIN and GAPDH.

\section{PAMPA-BBB}

Donor solution $(500 \mu \mathrm{M}$ or $250 \mu \mathrm{M})$ was prepared by diluting 10 or $5 \mathrm{mM}$ DMSO compound stock solution using phosphate buffer ( $\mathrm{pH} 7.4,0.01 \mathrm{M}$ ). Filter membrane was coated with $5 \mu$ l of BBB-specific lipid solution prepared dissolving $16 \mathrm{mg}$ of PBL (Avanti Lipids Polar, $141101 \mathrm{P})$ in $600 \mu \mathrm{l}$ of $n$-dodecane. Donor solution (150 $\mu \mathrm{l})$ was added to each well of the filter plate. To each well of the acceptor plate $300 \mu \mathrm{l}$ of solution (5\% DMSO in phosphate buffer) were added. Each compound was tested in triplicate. The sandwich was incubated for $24 \mathrm{~h}$ at room temperature under gentle shaking. After the incubation time, the sandwich plates were separated and $250 \mu$ of the acceptor plate were transferred to a UV quartz microtiter plate and measured by UV spectroscopy, using a Multiskan GO microplate spectrophotometer (Thermo Scientific) at $250-500 \mathrm{~nm}$ at step of $5 \mathrm{~nm}$. Reference solutions $(250 \mu \mathrm{l})$ were prepared diluting the sample stock solutions to the same concentration as that with no membrane barrier. The BBB permeability value $\log \mathrm{P}_{\mathrm{e}}$ is determined applying the equation:

$$
\begin{gathered}
\log P_{e}=\log \left\{C \cdot\left(-\ln \left(1-\frac{[\text { drug }]_{\text {acceptor }}}{[\text { drug }]_{\text {equilibrium }}}\right)\right)\right\}, \\
\text { where } C=\left(\frac{V_{D} \cdot V_{A}}{\left(V_{D}+V_{A}\right) \text { area } \cdot \text { time }}\right)
\end{gathered}
$$

In this equation, $\mathrm{V}_{\mathrm{A}}$ is the volume of the acceptor compartment $\left(0.3 \mathrm{~cm}^{3}\right), \mathrm{V}_{\mathrm{D}}$ is the donor volume $(0.15$ $\left.\mathrm{cm}^{3}\right)$, area is the accessible filter area $\left(0.24 \mathrm{~cm}^{2}\right)$, and time is the incubation time in seconds.

\section{Mice experiments}

Mice were purchased from Charles River Laboratories and maintained in the Animal Facility at Sapienza University of Rome. All procedures were performed in accordance with the Guidelines for Animal Care and Use of the National Institutes of Health with the approval of the Ethics Committee for Animal Experimentation (Prot. N 03/2013) of Sapienza University of Rome.

\section{In vivo treatment}

CD1 wild-type mice were treated intra-peritoneally with $20 \mu$ Moles/Kg of MC3629 ( $\mathrm{n}=8$ for each group). Treatment was performed at the age of 8 and 10 days post natal and mice were sacrificed at 12 days post natal. Brain and cerebellum tissues were collected for analysis. 


\section{Medulloblastoma xenografts}

DAOY-SLCs were stereotaxically implanted into the cerebellum of nude mice by using the following coordinates according to the atlas of Franklin and Paxinos: $6.6 \mathrm{~mm}$ posterior to the bregma; $1 \mathrm{~mm}$ lateral to the midline; and $2 \mathrm{~mm}$ ventral from the surface of skull of mice, under ketamine $(100 \mathrm{mg} / \mathrm{kg}$, i.p. $) / x y l a z i n e ~(10 \mathrm{mg} /$ $\mathrm{kg}$, i.p.) anesthesia. Cells $\left(2 \times 10^{5}\right.$ per $\left.3 \mu \mathrm{l}\right)$ were implanted at an infusion rate of $1 \mu \mathrm{l} / \mathrm{min}$. Mice were separated into two groups. Group $1(\mathrm{n}=8)$ was intraperitoneally treated with MC3629 (20 $\mu$ Moles/Kg) suspended in 10\% (2-Hydroxypropyl)- $\beta$-cyclodextrin $+1 \% \mathrm{DMSO}$ (Sigma), Group $2(\mathrm{n}=8)$ was treated with $10 \%$ (2-Hydroxypropyl)$\beta$-cyclodextrin $+1 \%$ DMSO (Sigma). After 21 days of treatment, animals were sacrificed and brains were formalin fixed and paraffin embedded. Brain tumor volume calculation: Serial thick coronal sections $(2 \mu \mathrm{m})$ starting from mesencephalon to the end of cerebellum were performed. The analysis was performed on 20 sections, sampled every $40 \mu \mathrm{m}$ on the horizontal plan of the cerebellum, in which the tumor was identified and outlined at 2.5X magnification.

Every $40 \mu \mathrm{m}$ of brain slice, hematoxylin and eosin (H\&E) staining was performed. Tumor area of every slice was evaluated with a microscope (Axio Imager M1 microscope) equipped with a motorized stage and software Image Pro Plus 6.2. The following formula was used to calculate brain tumor volume: tumor volume $=$ sum of (measured area for each slice $\mathrm{x}$ slice thickness $\mathrm{x}$ sampling frequency) [47].

\section{Immunohistochemistry}

Paraffin-embedded sections were deparaffinized, and stained with either H\&E or immunohistochemical stains as specified. Heat-induced epitope retrieval was performed with citrate buffer $\mathrm{pH}$ 6. Sections were incubated with ki67 primary antibody (Thermo Scientific) for $1 \mathrm{~h}$. Ki67 expression was expressed as percentages of total cells with labeled nuclei.

\section{CONFLICTS OF INTEREST}

No potential conflicts of interest were disclosed.

\section{GRANT SUPPORT}

This work was supported by IIT-Sapienza Project (AM, EF, EM), by the FP7 Projects REGPOT-CT2013-316149-InnovaBalt (PT), BLUEPRINT/282510 (AM) and A-PARADDISE/602080 (AM), by the COST action CM1406 Epigenetic Chemical Biology (PT, AM), Progetto Ateneo Sapienza (AM, EF), PRIN 2016 (prot. 20152TE5PK) (AM), AIRC 2016 (n. 19162) (AM), and NIH (n. R01GM114306) (AM).

\section{ACKNOWLEDGMENTS}

The authors wish to thank the IIT-CLNS@Sapienza imaging facility and Dr. Giovanna Peruzzi for her technical support with the Flow Cytometry Core Facility instruments.

\section{REFERENCES}

1. Sparmann A, van Lohuizen M. Polycomb silencers control cell fate, development and cancer. Nat Rev Cancer. 2006; 6:846-856.

2. Bracken AP, Dietrich N, Pasini D, Hansen KH, Helin K. Genome-wide mapping of Polycomb target genes unravels their roles in cell fate transitions. Genes Dev. 2006; 20:1123-1136.

3. Cao R, Wang L, Wang H, Xia L, Erdjument-Bromage H, Tempst P, Jones RS, Zhang Y. Role of histone H3 lysine 27 methylation in Polycomb-group silencing. Science. 2002; 298:1039-1043.

4. Czermin B, Melfi R, McCabe D, Seitz V, Imhof A, Pirrotta V. Drosophila enhancer of Zeste/ESC complexes have a histone $\mathrm{H} 3$ methyltransferase activity that marks chromosomal Polycomb sites. Cell. 2002; 111:185-196.

5. Margueron R, Reinberg D. The Polycomb complex PRC2 and its mark in life. Nature. 2011; 469:343-349.

6. Kim KH, Roberts CW. Targeting EZH2 in cancer. Nat Med. 2016; 22:128-134.

7. Bachmann IM, Halvorsen OJ, Collett K, Stefansson IM, Straume O, Haukaas SA, Salvesen HB, Otte AP, Akslen LA. EZH2 expression is associated with high proliferation rate and aggressive tumor subgroups in cutaneous melanoma and cancers of the endometrium, prostate, and breast. J Clin Oncol. 2006; 24:268-273.

8. Simon JA, Lange CA. Roles of the EZH2 histone methyltransferase in cancer epigenetics. Mutat Res. 2008; 647:21-29.

9. Yu J, Yu J, Rhodes DR, Tomlins SA, Cao X, Chen G, Mehra R, Wang X, Ghosh D, Shah RB, Varambally S, Pienta $\mathrm{KJ}$, Chinnaiyan AM. A polycomb repression signature in metastatic prostate cancer predicts cancer outcome. Cancer Res. 2007; 67:10657-63.

10. Crea F, Hurt EM, Mathews LA, Cabarcas SM, Sun L, Marquez VE, Danesi R, Farrar WL. Pharmacologic disruption of Polycomb Repressive Complex 2 inhibits tumorigenicity and tumor progression in prostate cancer. Mol Cancer. 2011; 10:40.

11. Northcott PA, Jones DT, Kool M, Robinson GW, Gilbertson RJ, Cho YJ, Pomeroy SL, Korshunov A, Lichter P, Taylor MD, Pfister SM. Medulloblastomics: the end of the beginning. Nat Rev Cancer. 2012; 12:818-834.

12. Alimova I, Venkataraman S, Harris P, Marquez VE, Northcott PA, Dubuc A, Taylor MD, Foreman NK, 
Vibhakar R. Targeting the enhancer of zeste homologue 2 in medulloblastoma. Int J Cancer. 2012; 131:1800-1809.

13. Smits M, van Rijn S, Hulleman E, Biesmans D, van Vuurden DG, Kool M, Haberler C, Aronica E, Vandertop WP, Noske DP. EZH2-regulated DAB2IP is a medulloblastoma tumor suppressor and a positive marker for survival. Clin Cancer Res. 2012; 18:4048-4058.

14. Suva ML, Riggi N, Stehle JC, Baumer K, Tercier S, Joseph JM, Suva D, Clement V, Provero P, Cironi L, Osterheld MC, Guillou L, Stamenkovic I. Identification of cancer stem cells in Ewing's sarcoma. Cancer Res. 2009; 69:1776-1781.

15. Chang CJ, Yang JY, Xia W, Chen CT, Xie X, Chao CH, Woodward WA, Hsu JM, Hortobagyi GN, Hung MC. EZH2 promotes expansion of breast tumor initiating cells through activation of RAF1- $\beta$-catenin signaling. Cancer Cell. 2011; 19:86-100.

16. Momparler RL, Cote S. Targeting of cancer stem cells by inhibitors of DNA and histone methylation. Expert Opin Investig Drugs. 2015; 24:1031-1043.

17. Kondo Y. Targeting histone methyltransferase EZH2 as cancer treatment. J Biochem. 2014; 156:249-57.

18. Tan J, Yang X, Zhuang L, Jiang X, Chen W, Lee PL, Karuturi RK, Tan PB, Liu ET, Yu Q. Pharmacologic disruption of Polycomb-repressive complex 2-mediated gene repression selectively induces apoptosis in cancer cells. Genes Dev. 2007; 21:1050-1063.

19. Gaudichon J, Milano F, Cahu J, DaCosta L, Martens AC, Renoir JM, Sola B, Deazaneplanocin A. Deazaneplanocin $\mathrm{a}$ is a promising drug to kill multiple myeloma cells in their niche. PLoS One. 2014; 9:e107009.

20. Knutson SK, Wigle TJ, Warholic NM, Sneeringer CJ, Allain CJ, Klaus CR, Sacks JD, Raimondi A, Majer CR, Song J, Scott MP, Jin L, Smith JJ, et al. A selective inhibitor of EZH2 blocks H3K27 methylation and kills mutant lymphoma cells. Nat Chem Biol. 2012; 8:890-896.

21. McCabe MT, Ott HM, Ganji G, Korenchuk S, Thompson C, Van Aller GS, Liu Y, Graves AP, Della Pietra A 3rd, Diaz E, LaFrance LV, Mellinger M, Duquenne C, et al. EZH2 inhibition as a therapeutic strategy for lymphoma with EZH2-activating mutations. Nature. 2012; 492:108-112.

22. Zhang P, de Gooijer MC, Buil LC, Beijnen JH, Li G, van Tellingen $\mathrm{O}$. $\mathrm{ABCB} 1$ and $\mathrm{ABCG} 2$ restrict the brain penetration of a panel of novel EZH2-Inhibitors. Int J Cancer. 2015; 137:2007-18.

23. Kumar A, Kumar V, Lightner J, Little A, Jutabha P, Endou H, Rice P, Reigan P, Vibhakar R, Harris P, Ilango IB, Venkataraman S, Nebout $M$, et al. EZH2 Inhibitor GSK126: Metabolism, drug transporter and rat pharmacokinetic studies. Medical Research Archives. 2015; 3 .

24. Po A, Ferretti E, Miele E, De Smaele E, Paganelli A, Canettieri G, Coni S, Di Marcotullio L, Biffoni M, Massimi L, Di Rocco C, Screpanti I, Gulino A. Hedgehog controls neural stem cells through p53-independent regulation of Nanog. EMBO J. 2010; 29:2646-2658.

25. Triscott J, Lee C, Foster C, Manoranjan B, Pambid MR, Berns R, Fotovati A, Venugopal C, O'Halloran K, Narendran A, Hawkins C, Ramaswamy V, Bouffet E, et al. Personalizing the treatment of pediatric medulloblastoma: polo-like kinase 1 as a molecular target in high-risk children. Cancer Res. 2013; 73:6734-44.

26. Verma SK, Knight SD. Recent progress in the discovery of small-molecule inhibitors of the HMT EZH2 for the treatment of cancer. Future Med Chem. 2013; 5:1661-1670.

27. Mai A, Cheng D, Bedford MT, Valente S, Nebbioso A, Perrone A, Brosch G, Sbardella G, De Bellis F, Miceli M, Altucci L. epigenetic multiple ligands: mixed histone/ protein methyltransferase, acetyltransferase, and class III deacetylase (sirtuin) inhibitors. J Med Chem. 2008; 51:2279-2290.

28. Mai A, Valente S, Cheng D, Perrone A, Ragno R, Simeoni S, Sbardella G, Brosch G, Nebbioso A, Conte M, Altucci L, Bedford MT. Synthesis and biological validation of novel synthetic histone/protein methyltransferase inhibitors. ChemMedChem. 2007; 2:987-991.

29. Palacios D, Mozzetta C, Consalvi S, Caretti G, Saccone V, Proserpio V, Marquez VE, Valente S, Mai A, Forcales SV, Sartorelli V, Puri PL. TNF/p38alpha/polycomb signaling to Pax7 locus in satellite cells links inflammation to the epigenetic control of muscle regeneration. Cell Stem Cell. 2010; 7:455-469.

30. Valente S, Lepore I, Dell'Aversana C, Tardugno M, Castellano S, Sbardella G, Tomassi S, Di Maro S, Novellino E, Di Santo R, Costi R, Altucci L, Mai A. Identification of PR-SET7 and EZH2 selective inhibitors inducing cell death in human leukemia U937 cells. Biochimie. 2012; 94:2308-2313.

31. Ciarapica R, Carcarino E, Adesso L, De Salvo M, Bracaglia G, Leoncini PP, Dall'agnese A, Verginelli F, Milano GM, Boldrini R, Inserra A, Stifani S, Screpanti I, et al. Pharmacological inhibition of EZH2 as a promising differentiation therapy in embryonal RMS. BMC Cancer. 2014; 14:139.

32. Ciarapica R, De Salvo M, Carcarino E, Bracaglia G, Adesso L, Leoncini PP, Dall'Agnese A, Walters ZS, Verginelli F, De Sio L, Boldrini R, Inserra A, Bisogno G, The Polycomb group, et al. The Polycomb group (PcG) protein EZH2 supports the survival of PAX3-FOXO1 alveolar rhabdomyosarcoma by repressing FBXO32 (Atrogin1/ MAFbx). Oncogene. 2014; 33:4173-4184.

33. Brooun A, Gajiwala KS, Deng YL, Liu W, Bolaños B, Bingham P, He YA, Diehl W, Grable N, Kung PP, Sutton S, Maegley KA, Yu X, Stewart AE. Polycomb repressive complex 2 structure with inhibitor reveals a mechanism of activation and drug resistance. Nat Commun. 2016; 7:11384.

34. Könczöl A, Müller J, Földes E, Béni Z, Végh K, Kéry A, Balogh GT. Applicability of a blood-brain barrier specific 
artificial membrane permeability assay at the early stage of natural product-based CNS drug discovery. J Nat Prod. 2013; 76:655-63.

35. Dubuc AM, Remke M, Korshunov A, Northcott PA, Zhan SH, Mendez-Lago M, Kool M, Jones DT, Unterberger A, Morrissy AS, Shih D, Peacock J, Ramaswamy V, et al. Aberrant patterns of H3K4 and H3K27 histone lysine methylation occur across subgroups in medulloblastoma. Acta Neuropathol. 2013; 125:373-84.

36. Tsang DP, Cheng AS. Epigenetic regulation of signaling pathways in cancer: role of the histone methyltransferase EZH2. J Gastroenterol Hepatol. 2011; 26:19-27.

37. Albert M, Helin K. Histone methyltransferases in cancer. Semin Cell Dev Biol. 2010; 21:209-220.

38. Martin C, Zhang Y. The diverse functions of histone lysine methylation. Nat Rev Mol Cell Biol. 2005; 6:838-849.

39. Zagni C, Chiacchio U, Rescifina A. Histone methyltransferase inhibitors: novel epigenetic agents for cancer treatment. Curr Med Chem. 2013; 20:167-185.

40. Bracken AP, Helin K. Polycomb group proteins: navigators of lineage pathways led astray in cancer. Nat Rev Cancer. 2009; 9:773-784.

41. Deb G, Singh AK, Gupta S. EZH2: not EZHY (easy) to deal. Mol Cancer Res. 2014; 12:639-653.
42. Xu B, Konze KD, Jin J, Wang GG. Targeting EZH2 and PRC2 dependence as novel anticancer therapy. Exp Hematol. 2015; 43:698-712.

43. Kuntz KW, Campbell JE, Keilhack H, Pollock RM, Knutson SK, Porter-Scott M, Richon VM, Sneeringer CJ, Wigle TJ, Allain CJ, Majer CR, Moyer MP, Copeland RA, Chesworth R. The importance of being me: magic methyls, methyltransferase inhibitors, and the discovery of tazemetostat. J Med Chem. 2016; 59:1556-64.

44. Miranda TB, Cortez CC, Yoo CB, Liang G, Abe M, Kelly TK, Marquez VE, Jones PA. DZNep is a global histone methylation inhibitor that reactivates developmental genes not silenced by DNA methylation. Mol Cancer Ther. 2009; 8:1579-1588.

45. Strober W. Trypan Blue Exclusion Test of Cell Viability. Current Protocols in Immunology. 2001; 21:3B:A.3B.1-A.3B.2.

46. Ronci M, Catanzaro G, Pieroni L, Po A, Besharat ZM, Greco V, Levi Mortera S, Screpanti I, Ferretti E, Urbani A. Proteomic analysis of human Sonic Hedgehog ( $\mathrm{SHH})$ medulloblastoma stem-like cells. Mol Biosyst. 2015; 11:1603-11.

47. Infante $\mathrm{P}$, Mori M, Alfonsi R, Ghirga F, Aiello F, Toscano S, Ingallina C, Siler M, Cucchi D, Po A, Miele E, D'Amico $\mathrm{D}$, Canettieri $\mathrm{G}$, et al. Gli1/DNA interaction is a druggable target for Hedgehog-dependent tumors. EMBO J. 2015; 34:200-17. 